\title{
Mining of methane from deposits subaquatic gas hydrates using OTEC
}

\author{
Vasyl Klymenko ${ }^{1 *}$, Yuriy Denysov ${ }^{2}$, Oleksandr Skrypnyk ${ }^{1}$, Serhii Kononchuk ${ }^{1}$, and \\ Ruslan Teliuta ${ }^{1}$ \\ ${ }^{1}$ Central Ukrainian National Technical University, Department of Electrical Engineering Systems and \\ Energy Management, 8 Universytetskyi Ave., 25006, Kropyvnytskyi, Ukraine \\ ${ }^{2}$ Odessa National Academy of Food Technologies, V.S. Martynovsky Institute of Refrigeration, \\ Cryotechnologies and Ecoenergetics, 112 Kanatna St, 65039, Odesa, Ukraine
}

\begin{abstract}
The article proposes to using Ocean Thermal Energy Conversion (OTEC) to increase the energy efficiency mining of methane from deposits subaquatic gas hydrates on the gas hydrate cycle (GHET), that will allow not to spend $10-15 \%$ of the extracted methane for power supply of a gas-producing complex (GPC). The circuit-technological solution GPC is described, according to which carbon dioxide is introduced into the gas hydrate layer to extract methane from gas hydrates. To improve the kinetics of the process of replacement of methane with carbon dioxide in gas hydrates, it is proposed do recirculation part of $\mathrm{CO}_{2}$. The scheme and cycle of gas-hydrate energy-technological installation GHET are given, which operates using OTEC and generates together with electricity for GPC, fresh water and cold. Based on the method proposed in this paper, a comparative thermodynamic analysis of installations using OTEC for Black Sea conditions was performed. by GHET and Anderson cycles and it is shown that the specific useful work obtained in the GHET cycle, approximately 3 times more, and energetic efficiency 1.5 times more.
\end{abstract}

\section{Introduction}

Subaquatic deposits of gas hydrates are a significant potential resource for methane production [1-3].

Among the most prepared for the practical implementation of methods of extracting methane from subaquatic gas hydrates can be divided into three main:

1) injection of warm water under pressure into the well;

2) depressive, according to which lower the pressure in the plast;

3 ) introduction into the gas hydrate layer of carbon dioxide (or a mixture of carbon dioxide and nitrogen) to replace methane gas [4-6].

The technologies that use these methods are based on a general principle: violation of the equilibrium state of gas hydrates in the formation, as a result of which the thermodynamic stability of the gas hydrate is lost and it decomposes into methane and fresh water [4].

*Corresponding author: klymvas@ukr.net 
For the first on-line assessment of energy nitrate for the production of methane from subaqueous gas hydrates, it is possible to speed up the operation of gas-powered offshore platforms [7].

However, a significant part of the deposits of subaquatic gas hydrates is in the waters of oceans and seas, the surface water of which has a temperature of $20-28^{\circ} \mathrm{C}$, and the bulk of water at depth has a temperature of $4-10^{\circ} \mathrm{C}$ [8-11].

There are many proposals for the use of such a temperature gradient for the production of electricity, fresh water and cold by means of ocean thermal energy conversion (OTEC) [10-16]. However, the methods, proponated for such a implementation, may have low thermodynamic efficiency. There are several suggestions for use OTEC with the use of gas hydrate technology in plants for the production of electricity, fresh water and cold [17-20], which have higher thermodynamic efficiency.

This paper considers the circuit-technological solution, according to which to increase the energy efficiency of methane production from subaquatic gas hydrates, it is proposed to supply energy to the gas production complex (GPC) in the installation using OTEC technology on the gas hydrate cycle (GHET). In such an installation in a closed cycle, the processes of formation and decomposition of methane gas hydrates under different thermobaric of methane for energy supply, and an additional advantage is the ability to produce fresh water and cold at the same time as electricity production.

\section{Gas production complex for development of deposits of subacqual gas hydrates using OTEC}

The paper considers a gas production complex for the development of subaquatic gas hydrates with the use of OTEC technology, which consists of a plant for methane production from subaquatic gas hydrates by injection of carbon dioxide and an installation using OTEC gas cycle technology for GPC energy supply.

\subsection{Scheme and technological solution of installation for methane extraction from underwater deposits of gas hydrates by injection of carbon dioxide into the plast}

Among the above, the most promising is the technology of development of subaquatic gas hydrate deposits, according to which carbon dioxide is injected into the gas hydrate layer to replace methane.

This technology has the following additional advantages:

1) the burial of $\mathrm{CO}_{2}$, which is a greenhouse gas;

2) the formed hydrates of $\mathrm{CO}_{2}$ ensure the integrity of the pore space of hydrate deposits.

Methane production by introducing $\mathrm{CO}_{2}$ into the gas hydrate formation is based on different values of equilibrium thermodynamic parameters of methane hydrate and $\mathrm{CO}_{2}$ hydrate: at the same pressures, the equilibrium temperature of $\mathrm{CO}_{2}$ hydrates is significantly higher than that of $\mathrm{CH}_{4}$ hydrates [21, 22]. In the presence of $\mathrm{CO}_{2}$, the composition of the gas atmosphere changes, which disrupts the equilibrium state of methane hydrate at these thermobaric parameters and leads, on the one hand, to the loss of its thermodynamic stability, and on the other to the formation of $\mathrm{CO}_{2}$ hydrates. Conditions for the decomposition of methane hydrate when injected into the $\mathrm{CO}_{2}$ system is determined, along with pressure and temperature, the composition of the gas mixture, the hydrate number of the mixed hydrate formed from this mixture, the heat of its formation. The kinetics of the substitution process and the size of the gas-hydrate contact surface, the presence of free water in the system and a number of the above thermodynamic factors also play a significant role. 
The results of experimental studies presented in [23] were taken into account during the development of the circuit-technological solution of the installation for methane extraction from subaquatic deposits of gas hydrates by injection of carbon dioxide. According to these results, the degree of substitution for these thermobaric conditions depends mainly on the concentration of $\mathrm{CO}_{2}$ in the gas mixture, which is in equilibrium with the hydrate and, thus, has no restrictions on its continuous pumping through the methane hydrate deposit. To calculate the kinetics of the substitution process, you can use a calculation method based on the stochastic model of the hydrate formation process [24] and the macrophysical model of the process [25].

In Fig. 1 shows a schematic an installation for the development of methane hydrate deposits in this way.

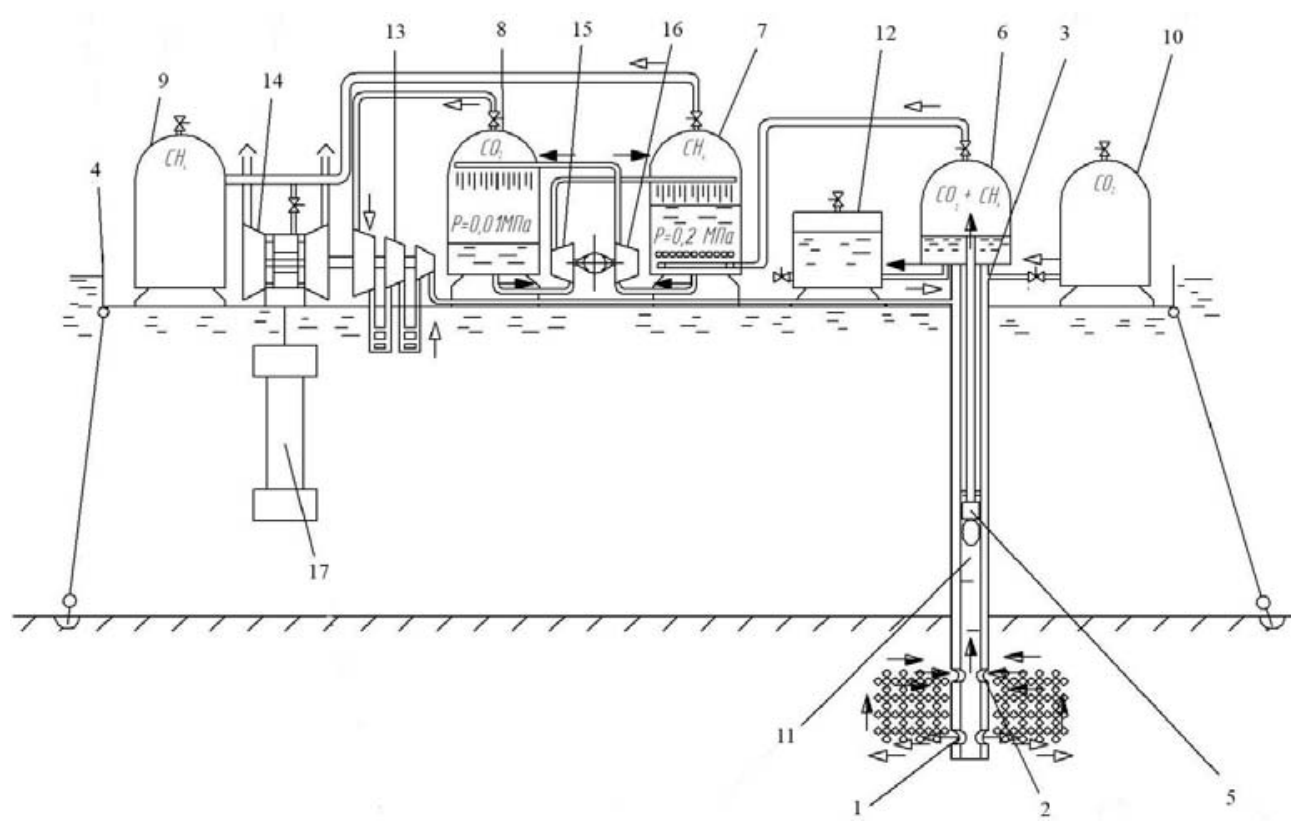

Fig. 1. Principled scheme of the installation for mining methane from subaquatic deposits of gas hydrates by injection of carbon dioxide into the plast: 1,2-well windows; 3 -window for the introduction of carbon dioxide into the intertube space of the well; 4 -platform; 5 -submersible electric pump; 6 - separator; 7 - water adsorber $\mathrm{CO}_{2} ; 8-\mathrm{CO}_{2}$ desorber; 9 - gasholder $\mathrm{CH}_{4} ; 10-\mathrm{CO}_{2}$ gasholder; 11 - pipe for lifting a suspension of methane and fresh water; 12 - fresh water tank; 13 - compressor for $\mathrm{CO}_{2}$ compression; 14 -gas turbine installation; 15 -pump; 16 -hydraulic turbine; 17 - GHET.

The installation works as follows. Carbon dioxide from the gasholder 10 is introduced into the bottomhole through the windows 1 of the well, and through the windows 2 pump the gas-water suspension by submersible electric pump 5 in the separator 6 to separate the gas phase consisting of a mixture of $\mathrm{CH}_{4}$ and $\mathrm{CO}_{2}$ from water. From the separator, water is discharged into the fresh water tank 12, and the gas mixture of methane and carbon dioxide is passed through a water absorber 7 , where carbon dioxide is absorbed by water, and methane is bubbled through water and sent to the gas holder of methane gas 9 . The water with dissolved $\mathrm{CO}_{2}$ is passed through a hydraulic turbine 16 and sent to the desorber 8 , where carbon dioxide is degassed from the water due to pressure drop and by means of the compressor 13 is sent for recirculation to the wellbore through the windows 1 . Simultaneously water from the desorber is recycled to the absorber 7. 
Recycle carbon dioxide (with a recirculation multiplicity factor $\mathrm{Kr}$, the value of which is, for example, within the values of 3-5), having a relatively high temperature after compression in the compressor 13 , is directed together with carbon dioxide from the gasholder 10 through the well into the face leads to the melting of part of the methane hydrates in the formation nearby and the release of fresh water and methane gas. As the pores of the formation move, the $\mathrm{CO}_{2}$ cools and replaces methane in the hydrates of the main part of the formation. This leads to the release of methane gas and preservation in the hydrate layer fed from the gasholder 10 carbon dioxide. The gaswater suspension is pumped out of the well by a submerged electric pump 5 into the separator 6, where the gas phase consisting of a mixture of $\mathrm{CH}_{4}$ and $\mathrm{CO}_{2}$, which is not part of the hydrates, is separated from the water. It should be noted that with increasing multiplicity of $\mathrm{CO}_{2}$ recycling, you can almost proportionally increase the yield of fresh water, but it will increase energy consumption in the installation for the development of methane-hydrate deposits.

Therefore, in this installation, the main part of methane is extracted by replacing $\mathrm{CH}_{4}$ in the composition of $\mathrm{CO}_{2}$ gas hydrates, and in addition methane and fresh water are extracted due to the melting of gas hydrates in the reservoir with excess recycled $\mathrm{CO}_{2}$. The analysis showed that for the energy supply of the gas production complex, which operates on the above technology, you need to spend about $10-15 \%$ of the extracted methane.

Therefore, if such a complex will be built in the conditions of possible use of OTEC, for example in the water near Black Sea [18] or in the Australia [26], it is advisable to generate electricity for energy production in a separate plant using OTEC gas hydrate cycle technology (GHET), in which working fluid is methane, which is extracted. Such a plant can be placed on the same platform 4 with a plant for extracting methane from subaquatic deposits of gas hydrates. In the case where the conditions for the use of OTEC may be seasonal: for example, for the Black Sea it is $4-5$ months, there is a need to supply gas to the GPC in another period to use a gas turbine unit 14 .

\subsection{Installation using OTEC gas hydrate cycle technology for power supply of gas production complex (GPC)}

Gas hydrates are supramolecular crystalline compounds of the clathrate-type inclusion, in which molecules of nonpolar or low-polar substances "incorporated" into the ice-like structure of water are held by van-der-Waals forces [21, 22]. Gas hydrates are formed and decomposed under certain thermobaric conditions in ranges convenient for implementation in cycles at small temperature differences.

This allows them to be used effectively as working fluids of OTEC systems for the production electricity, fresh water and cold. Currently, the most developed for the use of OTEK double-circuit installations that operate on the Anderson cycle [10-14], which is then considered for comparative thermodynamic analysis.

In Fig. 2 shows the operating cycle of the GHET (Fig. 2a) and the Anderson cycle (Fig. 2b) in $T-S$ coordinates, as well as the operating cycle of the GHET in the $P$ - $T$ diagram (Fig. 2c) (temperature $T_{c}=8^{\circ} \mathrm{C}$ and $T_{w}=24^{\circ} \mathrm{C}$ adopted for the conditions of the Black Sea) and the schematic diagram of the GHET (Fig. 3).

The $T-S$ coordinates (Fig. 2c) show the "quality" cycle of the gas hydrate installation, shown conditionally only for the processes of changing the parameters of hydrate-forming methane gas and without taking into account thermodynamic processes of changing the state of gas hydrates: clathrate compounds "methane + water".

Comparison of the cycle GHET plant and Anderson ammonia cycle plant shows that the slope of the equilibrium curve of hydrate is much more than the saturation curve of ammonia vapors. 
(a)

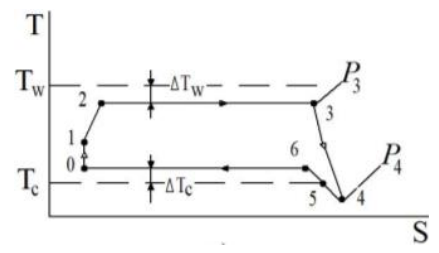

(b)

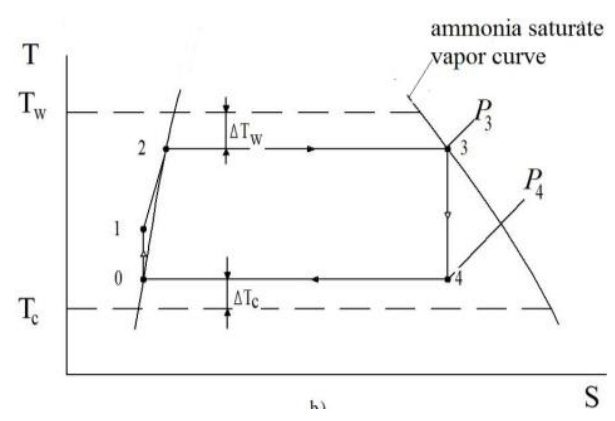

(c)

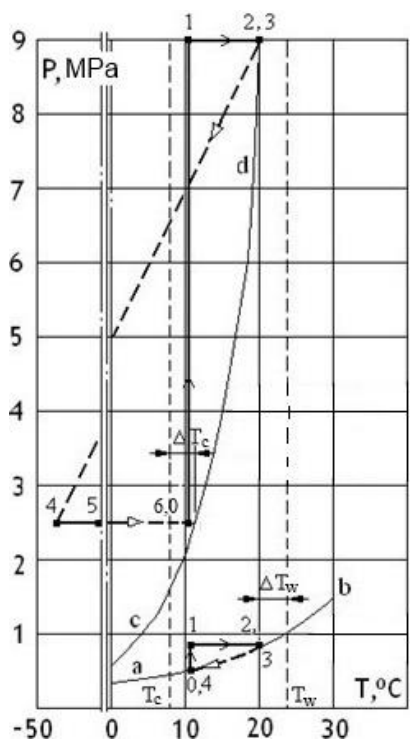

Fig. 2. GHET cycle in $T-S$ (Fig. 2a) and $P-T$ (Fig. 2c) diagrams and Anderson cycle (for ammonia) in $T-S$ diagram (Fig. 2b) (temperatures $T_{c}=8^{\circ} \mathrm{C}$ and $T_{w}=24^{\circ} \mathrm{C}$ are accepted for conditions of the Black Sea $[5,18]$ ): GHET cycle consists from the following processes: $0-1-$ the process of compression slurry of gas hydrate and water; 1-2 - heating gas hydrates; 2-3 - the melting of gas hydrates in the melter; 3-4-expansion of methane in the gas-turbine; 4-5-the heating of the gas in the cooling chamber; 5-6-0 - the formation of gas hydrates in the crystallizer; $\Delta T_{w}$ - temperature difference in the melter from the warm water; $\Delta T_{c}$ - temperature difference in the crystallizer from the cold water side; $c-d$-the equilibrium curve of hydrate formation system "sea water + methane" $[21,22]$; the Anderson cycle consists of the following processes: 0-1 - compression of liquid ammonia by a pump; 1-2 - heating of liquid ammonia; 2-3 - boiling of ammonia in the steam generator 1; 3-4-expansion of ammonia vapor in the steam turbine; 4-0 - condensation of ammonia vapor; $\Delta T_{w}$ - temperature difference in the evaporator from the warm water; $\Delta T_{c}$ - temperature difference in the condenser from the cold water side; $a-b$ - equilibrium saturation curve for ammonia [28].

As a result, for the same temperature difference between ocean surface and depth water, the expansion of working fluid in the turbine of the GHET plant is substantially greater than in the turbine of the plant using Anderson cycle, hence GHET produces greater work. Note, that this pattern holds for other working fluids also, for example, such as propane, R-22, R-134 etc. In the gas hydrate cycle, phase transitions with the formation / melting of a solid gas hydrate phase are used. The process of hydrate formation occurs at the contact of methane and sea water, and melting - with the release of methane and fresh water. An important feature of the GETU cycle is that it is closed to recycled methane and open to water: the installation includes seawater, and fresh water and brine.

The GHET plant operates as follows (Fig. 3): sea water and methane are sent to the crystallizer 1 at $T_{0}=8^{\circ} \mathrm{C}$ and a pressure of $P_{0}=2.5 \mathrm{MPa}$. As a result, gas hydrate are formed and heat of formation is removed with cold water pumping through a heat exchanger of the crystallizer. The mixture of hydrate and of brine is sent by screw 2 to the filter chamber 3 , where the hydrates are separated from the brine and washed with a small amount of fresh water in countercurrent. Hydrates which are washed from the brine are fed into the melter 4 where they are melted to yield fresh water and natural gas of high pressure $\left(P_{3}=9 \mathrm{MPa}\right)$. The heat of melting hydrate is fed with warm water pumping through the heat exchanger of the melter using the pump 9. 


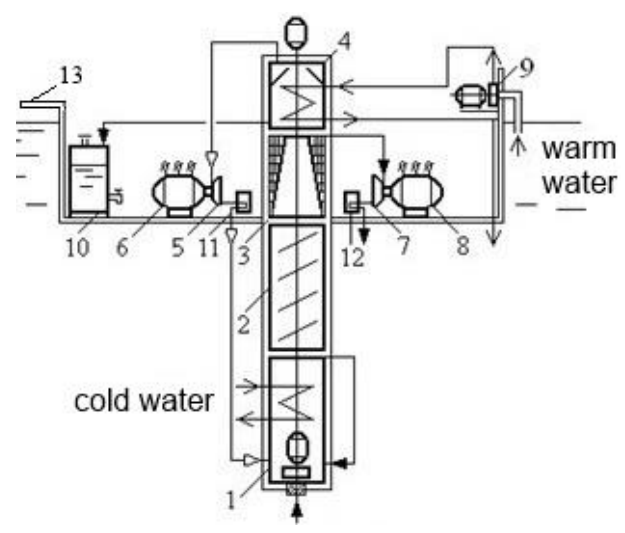

Fig. 3. Principled scheme of GHET: 1 - crystallizer; 2 -screw; 3 -filtering chamber; 4 -melter; 5 -gas turbine; 6-electric generator; 7-hydraulic turbine; 8 -electric generator; 9-pump; 10 - fresh water storage; 11 - refrigerator; 12 - heat exchanger; 13 - GPC platform.

Fresh water directed from the melting unit 4 in tank 10 as the useful product. Highpressure gas is supplied to the gas-turbine 5, where expands to the pressure of $P_{0}=2.5 \mathrm{MPa}$ and produces work to drive an electric generator 6 . Gas at a temperature $T_{4}=-45^{\circ} \mathrm{C}$ is directed from the turbine to the cooling chamber 11 as the cold source for the freezing of food products, where this gas is heated to $T_{5}=-20^{\circ} \mathrm{C}$ (process 4-5 shown in Fig. 2c) and then recycled within the crystallizer 1 .

The brine from the filter chamber 3 is directed to a hydraulic turbine 7 to drive an electric generator 8 and then at a temperature $T_{0}=10^{\circ} \mathrm{C}$ directed to the heat exchanger 12 for air conditioning.

\section{Comparative thermodynamic analysis of installations using OTES for gas hydrate cycle and Anderson cycle. Results and discussion}

Comparative analysis of the degree of perfection of the GHET and Anderson thermodynamic cycles (Fig. 2a-2c) can be done on the basis of the analysis of the coefficient of exergetical effectivity $[18,27]$ :

$$
\eta_{e x}=\frac{e_{u s}}{e_{s p}},
$$

where $e_{u s}-\mathrm{a}$ useful exergy (for Anderson cycle plant: $e_{u s}=l_{u s}$ and for GHET plant: $e_{u s}=\left(l_{u s}+e_{f r}+e_{q o}\right) ; l_{u s}=l_{t}-l_{p}-l_{s . w .}$ is useful work of the plant; $e_{f r}-$ a useful exergy of fresh water; $\mathrm{e}_{q o}-\mathrm{a}$ useful exergy of cold; $l_{t}-\mathrm{a}$ work of expansion of the working fluid within the turbine; $l_{p}-$ a work of compression of the working fluid within the pump; $l_{s . w}-\mathrm{a}$ work of circulation of sea water through the heat exchangers of evaporator/crystallizer and condenser/melter; $e_{s p}=e_{c} \cdot G_{c}$ is an exergy spent, which determined by reference to consumption of cold sea water $G_{c}$ used as a cold source.

The calculation of the values of $l_{t}, l_{p}, l_{s . w}$. which are part of the $l_{u s}$, can be performed according to the formulas given in $[18,28]$. It should be noted that in GHET you can also use the work of the brine flow in the hydraulic turbine, after separating it from the gas hydrates in the filter chamber, and the work of the fresh water flow formed by melting the gas hydrates. 
Exergy of useful products, which are additionally produced by the installation of GHET.

Exergy of fresh water $e_{f r}$ produced during melting of gas hydrates equals:

$$
e_{f r}=\frac{W_{\min } \cdot n \mu_{w}}{\mu_{g}},
$$

where $W_{\min }$ - a minimum work for seawater desalination, $\mathrm{kJ} / \mathrm{kg}[18] ; n-\mathrm{a}$ number of molecules of water that falls on a single molecule of natural gas $[21,22] ; \mu_{w}$ and $\mu_{g}-\mathrm{a}$ molecular mass of water and, respectively.

Exergy of the produced cold $e_{q o}$ :

$$
e_{q o}=e_{q o(g)}+e_{q o(b)},
$$

where $e_{q o(g)}$ - exergy cold of the gas stream used in the refrigeration chamber; $e_{q o(b)}-$ exergy cold brine stream used for air conditioning.

Exergy $e_{q o(g)}$ is defined by the expression:

$$
e_{q o(g)}=\frac{q_{0}}{\varepsilon_{k}},
$$

where $q_{0}, \mathrm{~kJ} / \mathrm{kg}$ of gas is a cold of the gas stream at the outlet of the gas turbine:

$$
q_{0}=c_{p} \cdot\left(T_{5}-T_{4}\right)
$$

where $\varepsilon_{k}-$ a coefficient of refrigerating for the reverse Carnot cycle, built on the average heat removal temperature $T_{a v}$ for the cooled medium in the refrigeration chamber and the temperature of $T_{w}$ environment - is a temperature for the warm water on the surface of an ocean $[18,27]$ :

$$
\varepsilon_{k}=\frac{T_{a v}}{T_{w}-T_{a v}} .
$$

Exergy $e_{q o(b)}$ is determined by a ratio similar to (4-6).

The exergy spent: $e_{s p}=e_{c}$.

Here $e_{c . w}$ is an exergy of $1 \mathrm{~kg}$ of deep cold sea water:

$$
e_{c}=c \cdot\left[\left(T_{c}-T_{w}\right)-T_{w} \cdot \ln \left(\frac{T_{\mathcal{C}}}{T_{w}}\right)\right],
$$

where $c$ - a heat capacity of deep cold sea water; $T_{c}$ - a temperature of deep cold sea water; $T_{w}$ - temperature of the environment: is a temperature for the warm water on the surface of an ocean $[18,27]$.

a) the flow of deep cold sea water for Anderson cycle plant is:

$$
G_{c(A)}=\frac{r_{a}}{c \cdot \Delta T_{k}}
$$

where $r_{a}$ - a heat of condensation of ammonia; $c$ - a heat capacity of sea water; $\Delta T_{k}$ - the difference in temperature of cold water when removing the heat of condensation in the condenser;

b) the flow of deep cold oceanic water within the GHET plant:

$$
G_{c(G)}=\frac{\Delta H_{G}}{c \cdot \Delta T_{k r}},
$$


where $\Delta H_{G}-$ a heat of formation of gas hydrate; $\Delta T_{k r}$ - the difference in temperature of cold water when removing heat from the formation of gas hydrates in the crystallizer.

Table 1 shows the results of calculations according to the above method of comparative thermodynamic analysis of specific values ( $\mathrm{kJ} / \mathrm{kg}$ of working fluid) of useful work, exergy, as well as values of exergetic efficiency of installations using OTEC for Black Sea conditions (installation cycles are shown in Fig. 2).

Table 1. Results of calculation specific values ( $\mathrm{kJ} / \mathrm{kg}$ of working fluid) of useful work, exergy, exergetic efficiency of installations using OTEC

\begin{tabular}{|l|l|l|l|l|}
\hline \multirow{5}{*}{ No. } & \multicolumn{2}{|c|}{$\begin{array}{c}\text { The plant on cycle of Anderson } \\
\text { (working fluid }- \text { ammonia) }\end{array}$} & \multicolumn{2}{|c|}{$\begin{array}{c}\text { The plant with a gas hydrate cycle } \\
\text { GHET (working fluid of } \\
\text { closed-loop is a methane) }\end{array}$} \\
\cline { 2 - 5 } & $\begin{array}{c}\text { The formula } \\
\text { for calculating }\end{array}$ & Calculation & $\begin{array}{c}\text { The formula } \\
\text { for calculating }\end{array}$ & Calculation \\
\hline Useful work, $l_{u s}$ & $l_{u s}=l_{t}-l_{\mathrm{p}}-l_{s}$ & 14.0 & $l_{u s}=l_{t}-l_{p}-l_{s}$ & 39.3 \\
\hline Exergy fresh water, $e_{f r}$ & & & $e_{f r}=W_{\min } \cdot n \cdot \mu_{w} / \mu_{g}$ & 14.1 \\
\hline Exergy cold gas, $e_{q o(g)}$ & & & $e_{q o(g)}=q_{0} / \varepsilon_{\kappa}$ & 12.8 \\
\hline Exergy cold brine, $e_{q o(b)}$ & & & $e_{q o(b)}$ & 1.4 \\
\hline Exergy spent, $e_{s}$ & $e_{s}=e_{c} G_{c(A)}$ & 173.0 & $e_{s}=e_{c .} G_{c(G)}$ & 540.0 \\
\hline $\begin{array}{l}\text { The exergy efficiency } \\
\text { of the plant, } \eta_{e x}\end{array}$ & $\eta_{e x}=l_{u s} / e_{s p}$ & 0.08 & $\eta_{\mathrm{ex}}=\left(l_{u s}+e_{f r}+e_{q 0}\right) / e_{s p}$ & 0.12 \\
\hline
\end{tabular}

\section{Conclusions}

The circuit-technological solution of the gas production complex for the development of subaquatic deposits of gas hydrates is considered and it is proposed to increase its energy efficiency by using OTEC technology for gas hydrate cycle, closed on methane and open on water (GHET). This will allow not to spend $10-15 \%$ of the extracted methane gas for energy supply of the gas production complex and in addition to electricity in GHET to produce fresh water and cold.

Based on the proposed methodology is determined the thermodynamic efficiency of installations using OTEC using Anderson and GHET cycles for Black Sea conditions.

The calculated values useful work, attributed to $1 \mathrm{~kg}$ of methane in the GHET installation and $1 \mathrm{~kg}$ of ammonia in the Anderson installation, are almost three times higher for GHET, and exergy efficiencies of installations in GHET and Anderson cycles are $12 \%$ and $8 \%$, respectively. In addition, part of the extracted methane will not be burned during the operation of the gas production complex, which will reduce the negative impact on the environment.

However, it should be noted that the construction of the GHET plant, which uses OTEC on the gas hydrate cycle, will require a fairly large investment and determine the feasibility of its application in specific conditions of development of subaquatic deposits of gas hydrates is required on the basis of technical and economic analysis.

This work was carried out within the project "Improving the efficiency of the use of gas hydrate devices in heat technology systems" (State registration NRK 0116 U 001894).

\section{References}

1. Kvenvolden, K.A., Ginsburg, G.D., \& Soloviev, V.A. (1993) Worldwide distribution of subaquatic gas hydrates. Geo-Marine Letters, (13), 32-40. https://doi.org/10.1007/BF01204390

2. Makogon, Yu. F. (2010). Gazogidraty. Istoriya izucheniya i perspektivy osvoyeniya. Geologiya $i$ Poleznyye Iskopayemyye Mirovogo Okeana, 2(20), 5-21. 
3. Bondarenko, V., Svietkina, O., \& Sai, K. (2017). Study of the formation mechanism of gas hydrates of methane in the presence of surface-active substances. Eastern-European Journal of Enterprise Technologies, 5(6 (89)), 48-55. https://doi.org/10.15587/1729-4061.2017.112313

4. Denisov, Y.P., \& Klymenko, V.V. (2014). Sravnitel'nyy analiz tekhnologiy dobychi gazogidratnogo metana. Naukovyy Zhurnal (Heolohiya. Hirnytstvo. Naftohazova Sprava. Enerhetyka), 1(3), 13-22.

5. Vytiaz. O.Yu., Femiak, Ya.M., \& Ovetskyi, S.O. (2014). Klasyfikatsiia sposobiv vydobuvannia metanu z hazohidratnykh pokladiv dna Chornoho moria. Rozvidka ta Rozrobka Naftovykh $i$ Hazovykh Rodovyshch, 1(50), 13-23.

6. Goshovskiy, S.V., \& Zur'yan, A.V. (2018). Sposoby i tekhnologii dobychi gaza metana iz akvalnykh gazogidratnykh formirovaniy. Mineralni Resursy Ukrainy, (3), 124-127. https://doi.org/10.31996/mru.2018.4.26-31

7. Prohnozne otsiniuvannia ta khid osvoiennia vydobuvannia netradytsiinykh dzherel pryrodnoho hazu v umovakh konkurentsii na enerhetychnomu rynku. (2013). Kyiv, Ukraina: Viddil informatsiino analitychnoho zabezpechennia zarubizhnoiu informatsiieiu NTTSE NEK "Ukrenerho".

8. DaRosa, AldoVieira. (2009). Chapter 4 - Ocean thermal energy converters. Fundamentals of Renewable Energy Processes, 139-152. https://doi.org/10.1016/B978-0-12-374639-9.00004-X

9. Ocean thermal energy conversion. (2019). Retrieved from https://en.wikipedia.org/wiki/Ocean thermal_energy_conversion

10. William, H., Avery, Chih Wu. (1994). Renewable energy from the ocean: A guide to OTEC. New York, United States: Oxford University Press, 446 p.

11. Korobkov, V.A. (1986). Ocean energy conversion. Saint Petersburg, Russian Federation: Shipbuilding, $280 \mathrm{p}$.

12. Anderson, J.H. (1967). Sea water power plant. Patent US 3312054.

13. Faizal, M., \& Ahmed, M.R. (2013). Experimental studies on a closed cycle demonstration OTEC plant working on small temperature difference. Renewable Energy, (51), 234-240. https://doi.org/10.1016/j.renene.2012.09.041

14. Hawaii first to harness deep ocean temperatures for power. (2019). Retrieved from https://www.scientificamerican.com/article/hawaii-first-to-harness-deep-ocean-temperatures-forpower/

15. Semmari, H., Stitou, D., \& Mauran, S. (2012). A novel Carnot-based cycle for ocean thermal energy conversion. Energy, 43(1), 361-375. https://doi.org/10.1016/j.energy.2012.04.017

16. Masanori Kobayashi. (2015). Potential role of deep seawater for cooling and air conditioning in small island nations. ESMAP Knowledge Exchange Forum "Sustainable Energy For SIDS", 1-22.

17. Buchanan, A.B. (1962). Removing salt from sea water. Patent US 3027320.

18. Klymenko, V.V. (1974). The use of natural sea water temperature difference to produce fresh water and cold. Refrigeration Equipment and Technology, (19), 75-79.

19. Denisov, Y.P., \& Klymenko, V.V. (2016). Plant gas-hydrate for produce electricity and fresh water. The News of the Polytechnical Institute, 3(126), 65-72.

20. Denisov, U.P., Klimenko, V.V., Rybicki, C., \& Martinenko, V. (2017). Technology for development of methane-hydrate deposits jointly with receiving fresh water. AGH Drilling, Oil, Gas, 34(2), 531. https://doi.org/10.7494/drill.2017.34.2.531

21. Makogon, Yu.F. (1974). Hydrates of natural gases. Moscow, Russian Federation: Nedra, 208 p.

22. Makogon, Yu.F. (1997). Hydrates of hydrocarbons. Tulsa, United States: Penn Well, 504 p.

23. Voronov, V.P., Gorodetskiy, E.E., Muratov, A.R., \& Podnek, V.E. (2014). Issledovanie zamescheniya metana, soderzhaschegosya $\mathrm{v}$ gidrate, uglekislyim gazom pri siklicheskom dobavlenii uglekislogo gaza i otkachke gazovoy smesi, sosuschestvuyuschey s gidratom. Aktualnyie Problemy Nefti i Gaza, 1(9), 1-9.

24. Klymenko, V., Gutsul, V., Bondarenko, V., Martynenko, V., \& Stets, P. (2019). Modeling of the kinetics of the gas hydrates formation on the basis of a stochastic approach. Solid State Phenomena, (291), 98-109. https://doi.org/10.4028/www.scientific.net/ssp.291.98

25. Klymenko, V.V., \& Bandurina, O.V. (2012). Makrofizychna model protsesu zamishchennia dvooksydom vuhletsiu metanu u hazohidratnykh pokladakh. Visnyk KrNU imeni Mykhayla Ostrohradskoho, 6(77), 79-82. 
26. Koltun, P., \& Klymenko, V. (2016). Methane Hydrates - Australian perspective. Mining of Mineral Deposits, 10(4), 11-18. https://doi.org/10.15407/mining10.04.011

27. Martynovsky, V.S. (1972). Analysis of real thermodynamic cycles. Moscow, Russian Federation: Energia, $216 \mathrm{p}$.

28. Pavlov, K.F., Romankov, P.G., \& Noskov, A.A. (1981). Examples and problems at the rate of processes and apparatuses of chemical technology. Saint Petersburg, Russian Federation: Chemistry, $560 \mathrm{p}$. 